\title{
Evaluation of the Deterioration Degree of Insulators for Breakers Using Chemical Analysis and the Mahalanobis-Taguchi (MT) Method
}

\author{
Shinsuke Miki Member (Mitsubishi Electric Corporation) \\ Hiroshi Okazawa Non-member (Mitsubishi Electric Corporation) \\ Hiroshi Inujima Member (Graduate School of IPS, Waseda University)
}

Keywords: evaluation of deterioration degree, insulators, breakers, Mahalanobis-Taguchi method, chemical analysis

To prevent an unexpected power outage resulting from an accident, technology is needed for evaluating the deterioration degree of insulators with great accuracy and nondestructively on-site. Studies have been conducted mainly on electrical evaluation methods such as partial electric discharge and megohmmeters. However, to date it has been possible to evaluate insulator abnormalities by these methods only, and it cannot be said that they are sufficienty reliable. This paper describes our novel evaluation technique of the deterioration degree of insulators for breakers, which uses a chemical analysis and the MT method to improve the evaluation accuracy and the range of the deterioration degree that can be evaluated.

New insulators for breakers, as well as those already used commercially were sampled. In addition to the chemical analyses of ion concentration, color difference, gloss, and componential analysis, surface resistivity was measured as reference data. Figure 1 shows the concept chart of the evaluation method that applies the MT method. The main objective of the MT method is to introduce a scale based on all input characteristics to measure the degree of abnormality. Mahalanobis distance is used to construct such a scale. The larger the sample's degree of abnormality becomes, the larger the Mahalanobis distance from the reference space (data group of new insulators). Figure 2 shows the results of a comparison between the Mahalanobis distance calculated from the chemical analysis results and the actual measurement results for surface resistivity. We confirmed that the deterioration degree of insulators could be evaluated by this technique because a linear relationship existed between the results judged by the MT method and the actual measurement results for surface resistivity.

Surface resistivity can be obtained with great accuracy (average \pm one order of magnitude) by this technology. However, it is impossible to mesure the surface resistivity between $10^{9} \Omega$ and $10^{16} \Omega$ by electrical methods and the measured results for used insulators fluctuated by about five orders of magnitude when the humidity was not constant. From these results, it may be concluded that in comparison



Fig. 1. Concept chart of evaluation of insulators using the MT method

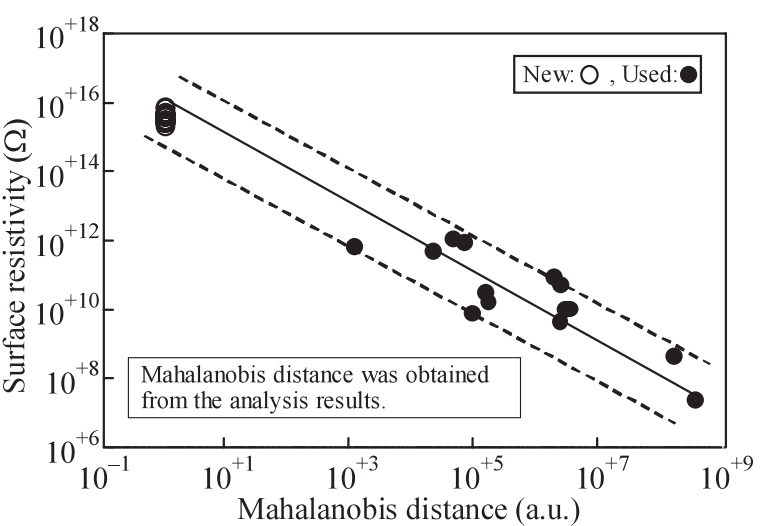

Fig. 2. Relationship between the Mahalanobis distance and surface resistivity

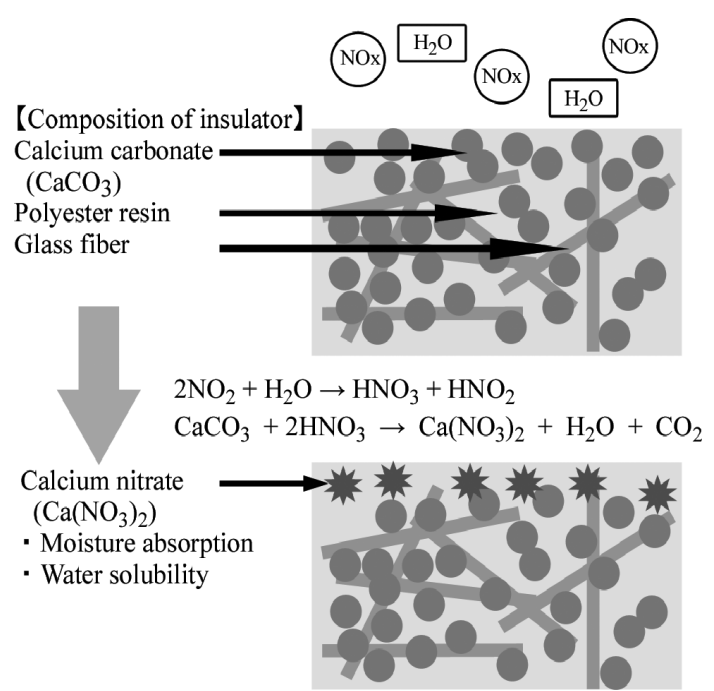

Fig. 3. Mechanism of surface resistivity reduction

to electrical methods, the evaluation accuracy has been improved by about three orders of magnitude and the range of the deterioration degree that could be evaluated was expanded by about seven orders of magnitude.

In addition, it was clarified that the main mechanism of surface resistivity reduction was due to NOx and SOx in the air. The mechanism due to NOx is as follows (Fig. 3).

(1) Nitric acid is generated by the reaction of NOx with water.

(2) Calcium nitrate is generated by the reaction of nitric acid with calcium carbonate (the insulator's filling material).

(3) The insulator's surface resistivity is reduced since calcium nitrate is a deliquescent ion compound. 


\title{
化学的分析とマハラノビス・タグチ（MT）法の適用による 遮断器用絶縁物の劣化評価
}

$\begin{array}{lll}\text { 正 員 三木 伸介* 非会員 岡澤 周** } \\ \text { 正員 犬島 浩*** } & & \end{array}$

\author{
Evaluation of the Deterioration Degree of Insulators for Breakers Using Chemical \\ Analysis and the Mahalanobis-Taguchi (MT) Method \\ Shinsuke Miki*, Member, Hiroshi Okazawa**, Non-member, Hiroshi Inujima***, Member
}

\begin{abstract}
We have developed a novel evaluation technique of the deterioration degree of insulators for breakers using a chemical analysis and the Mahalanobis-Taguchi (MT) method. It is possible to evaluate the deterioration degree with great accuracy and nondestructively on-site by this technique without the effect of humidity and external noise such as electromagnetic wave. The mechanism of insulator's surface resistivity reduction was clarified, and it was found that the deterioration degree of insulators could be evaluated by this technique because a linear relationship existed between the results judged by the MT method and the actual measurement results for surface resistivity. In comparison to electrical methods such as partial electric discharge and megohmmeters, the evaluation accuracy has been improved by three digits and the range of the deterioration degree that could be evaluated was expanded by seven digits.
\end{abstract}

キーワード : 劣化評価, 絶縁物, 遮断器, マハラノビス・タグチ法, 化学的分析

Keywords: evaluation of deterioration degree, insulators, breakers, Mahalanobis-Taguchi method, chemical analysis

\section{1. はじめに}

受配電設備は電気エネルギーを工場や建物へ供給する役 目を負っている設備であり, 信頼性, 安定性を確保して稼 動することが要求される。受配電設備の信頼性を支配する 絶縁物が長期間にわたる使用により劣化し電気的トラブル が発生すると，生産損失や設備補修など工場や建物に与え る影響が大きいため，精度の良い絶縁物の評価技術が望ま れている。

絶縁物の評価法としてこれまで絶縁抵抗測定や部分放電 測定等の電気的評価法が主に研究されてきたが(1) (4), 評価 精度は十分と言えないのが現状である。電気的評価法は湿 度や電磁波ノイズの影響を強く受け，測定する季節，時間，

\footnotetext{
* 三菱電機 (株) 先端技術総合研究所

于 661-8661 尼崎市塚口本町 8-1-1

Advanced Technology R\&D Center, Mitsubishi Electric Corporation

8-1-1, Tsukaguchi-honmachi, Amagasaki 661-8661

** 三菱電機 (株) 受配電システム製作所

干763-8516 丸亀市蓬莱町 8

Power Distribution System Center, Mitsubishi Electric Corporation

8, Horai-cho, Marugame 763-8516

*** 早稲田大学大学院 情報生産システム研究科

厂 808-0135 北九州市若松区ひびきの 2-7

Graduate School of IPS, Waseda University

2-7, Hibikino, Wakamatsu-ku, Kita-Kyushu 808-0135
}

及び周囲環境により結果が大きく異なる。評価精度が不十 分なのは, 絶縁物の劣化メカニズムに基づいた評価を実施 していないことが一因であると考えられる。また，これら の方法では電気的な異常を検出するため, 検出可能な範囲 は約 $10^{9} \Omega$ 以下の絶縁抵抗であり，異常検出の域をでてい ない。電気的トラブルを未然に防止するとともにメンテナ ンス周期を適正化し保守コストを削減するには, 電気的な 異常が発生する以前から劣化度を定量的に精度良く評価す ることが重要である。

本論文では絶縁劣化評価精度の向上と評価可能な範囲の 拡大を目的に, 湿度や電磁波ノイズの影響を受けない化学 的方法で遮断器用絶縁物を分析し, 分析結果を品質工学の 1 手法である MT 法で評価した。化学的分析は, 絶縁物付 着イオン濃度, 色彩, 光沢等である。これらのデータを MT 法で評価した結果と実験室で行った表面抵抗率測定結果は 高い相関性があったことから，本手法により受配電設備の 高精度な絶縁劣化評価が可能であることを確認した。さら に絶縁物の劣化メカニズムを明確化し, 電気的な異常が発 生しない段階での劣化度の把握が可能になったので, その 詳細を報告する。

\section{2. 評価対象}

受配電設備は多数の部品から構成されているが, 本報告 
では遮断器用絶縁物を評価対象として取りあげた。絶縁物 は定期点検等で交換が困難あるいは交換に費用が嵩む非修 理系の部品であり，経年劣化により事故が発生すると影響 が甚大であることから，受配電設備の寿命を決定する重要 部品となっている。

絶縁物が劣化する要因として一般的に熱劣化, 電圧劣化, 機械的劣化, 及び環境劣化が考えられる(1)。受配電設備内 部の温度は外気温 $+20^{\circ} \mathrm{C}$ 程度であり变圧器等と比較して使 用温度が低いため, 絶縁物の熱劣化は発生しにくい。また, 常時運転しているため運転・停止の過渡電圧がほとんどな いこと，製品出荷時に絶縁物のボイド等がないことを確認 しているため放電が発生しないことから電圧劣化も絶縁物 劣化の主因でないと考えられる。受配電設備は振動やヒー トサイクルが小さいことから, 絶縁物の機械的劣化も発生 しにくい。これらを考慮し絶縁物の表面における環境劣化 に着目して評価技術の開発を行った。

絶縁物表面の劣化度は使用環境によって大きく影響され， 複数の要因によって劣化が進展すると予想される。表面劣 化による絶縁破壊プロセスは一般的に，「(1)絶縁物表面の 抵抗低下，（2)漏れ電流によるジュール熱で局部的な乾燥 帯が形成，(3) 乾燥帯への電圧集中によりシンチレーショ ン放電が発生，（4)放電による有機物の炭化，炭化導電路 の形成による絶縁破壞」と考えられている ${ }^{(2)}$ 。絶縁物の環 境劣化を評価するには，抵抗低下の原因となる絶縁物表面 の化学変化を明確にすることが必要である。

以上より本報では遮断器用絶縁物の表面における環境劣

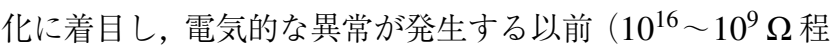
度の抵抗）から劣化評価を行うために，絶縁物の表面を化 学的方法により分析した。

\section{3. 実験方法}

〈3.1〉 サンプル 遮断器用絶縁物 $(41.0 \times 20.5 \times$ $31.5 \mathrm{~cm})$ の新品と市場使用品をサンプルとした。絶縁物 の成分を表 1 に示す。絶縁物はポリエステル樹脂，炭酸力 ルシウム, ガラス繊維等からなり, サンプル数は新品が 16 個 (ロットが異なる)，市場使用品が 14 個である。市場使用 品の設置場所と区分を表 2 に示す。使用年数は 5 15 年で ある。また，他の絶縁物への本技術の展開可否を評価する ために，木粉基材フェノール絶縁物 $(11.8 \times 16.1 \times 19.2 \mathrm{~cm})$ についても評価を実施した。

$\langle 3 \cdot 2\rangle$ 評価項目と装置・測定条件遮断器用絶縁物 の新品と市場使用品ついて, 色彩 - 光沢測定 (4 項目), 成

表 1 絶縁物の成分

Table 1. Composition of insulator.

\begin{tabular}{llr}
\hline \multicolumn{2}{c}{ Composition } & Content $(\%)$ \\
\hline Resin & Polyester resin & $20 \sim 30$ \\
Filler & Calcium carbonate & $55 \sim 75$ \\
Reinforcer & Glass fiber & $10 \sim 25$ \\
Additive & Antioxidant etc. & $3 \sim 5$ \\
\hline
\end{tabular}

分分析 (6 項目)，イオン付着量分析 (9 項目) の合計 19 項 目による化学的分析と外観観察，表面抵抗率測定を行った。 装置と測定条件を表 3 に示す。色彩，光沢は絶縁物の表面 を直接測定した。赤外分析は表面層をサンプリングし，透 過法により分析した。イオン付着量分析は純水を含ませた ろ紙を絶縁物表面に約 1 分間押し当て，付着イオンをろ紙 に回収してイオンクロマトグラフで分析した。表面抵抗率 は比較データとして取得した。絶縁物の表面に櫛形電極を 蒸着し，恒温恒湿槽を用いて湿度 $50 \%$, 温度 $20^{\circ} \mathrm{C}$ の条件 下で測定した。

表 2 遮断器用絶縁物の設置場所と区分

Table 2. Location and cubicle type of insulators for breakers.

\begin{tabular}{cllc}
\hline $\begin{array}{c}\text { Sample } \\
\text { No. }\end{array}$ & \multicolumn{1}{c}{ Location } & Cubicle type & $\begin{array}{c}\text { Elapsed time } \\
\text { (years) }\end{array}$ \\
\hline $1 \sim 16$ & \multicolumn{1}{c}{-} & - \\
17 & Hino City, Tokyo & Indoor type & 6 \\
18 & Hikawa-gun, Shimane & outdoor type & 7 \\
19 & Chuo-ku, Tokyo & outdoor type & 7 \\
20 & Matsuto City, Ishikawa & Indoor type & 5 \\
21 & Adachi-ku, Tokyo & outdoor type & 8 \\
22 & Akashi City, Hyogo & outdoor type & 6 \\
23 & Tohaku-gun, Tottori & outdoor type & 12 \\
24 & Saku City, Nagano & outdoor type & 5 \\
25 & Nagoya City, Aichi & outdoor type & 8 \\
26 & Nerima-ku, Tokyo & outdoor type & 15 \\
27 & Osaka City, Osaka & outdoor type & 8 \\
28 & Omiya City, Saitama & outdoor type & 7 \\
29 & Konan-ku, Kanagawa & outdoor type & 7 \\
30 & Ota-ku, Tokyo & outdoor type & 6 \\
\hline & $* 1 \sim 16$ : New samples & &
\end{tabular}

表 3 装置·測定条件

Table 3. Apparatus and measurement conditions.

\begin{tabular}{|c|c|c|}
\hline Analysis item & apparatus & item and condition \\
\hline Coloration & $\begin{array}{l}\text { Chroma meter } \\
\text { MINOLTA CR321 }\end{array}$ & Color mode: Lab \\
\hline Gloss & $\begin{array}{l}\text { Gloss meter } \\
\text { MINOLTA GM268 }\end{array}$ & $\begin{array}{l}\text { Insertion reflection } \\
\text { angle: } 60^{\circ}, 85^{\circ}\end{array}$ \\
\hline $\begin{array}{l}\text { Infrared } \\
\text { analysis }\end{array}$ & $\begin{array}{l}\text { Infrared } \\
\text { spectrophotometer } \\
\text { JEOL JIR-5500 }\end{array}$ & $\begin{array}{l}\text { Resolution: } 4 \mathrm{~cm}^{-1} \\
\text { Integration times: } 30\end{array}$ \\
\hline \multirow{2}{*}{ Ion analysis } & $\begin{array}{l}\text { Iom chromatograph } \\
\text {-Cation- } \\
\text { YOKOGAWA } \\
\text { IC7000S }\end{array}$ & $\begin{array}{l}\text {-Cation- } \\
\text { Column: YOKOGAWA } \\
\text { Exelpak ICS-C15 } \\
\text { Flow velocity: } \\
1.0 \mathrm{ml} / \mathrm{min}\end{array}$ \\
\hline & $\begin{array}{l}\text {-anion- } \\
\text { DIONEX 2010i }\end{array}$ & $\begin{array}{l}\text {-anion- } \\
\text { Column: DIONEX } \\
\text { IonpakCS3 } \\
\text { Flow velocity: } \\
1.5 \mathrm{ml} / \mathrm{min}\end{array}$ \\
\hline $\begin{array}{l}\text { Surface } \\
\text { resistivity }\end{array}$ & $\begin{array}{l}\text { pA Metrer / DC } \\
\text { Voltage Source } \\
\text { HEWLETT- } \\
\text { PACKARD 4140B }\end{array}$ & $\begin{array}{l}\text { Voltage: } 100 \mathrm{~V} \\
\text { Humidity: } 50 \% \\
\text { Temperature: } 20^{\circ} \mathrm{C} \\
\text { Electrode: Ctenoid } \\
\text { electrode, W687mm, } \\
\text { L0.3mm }\end{array}$ \\
\hline
\end{tabular}




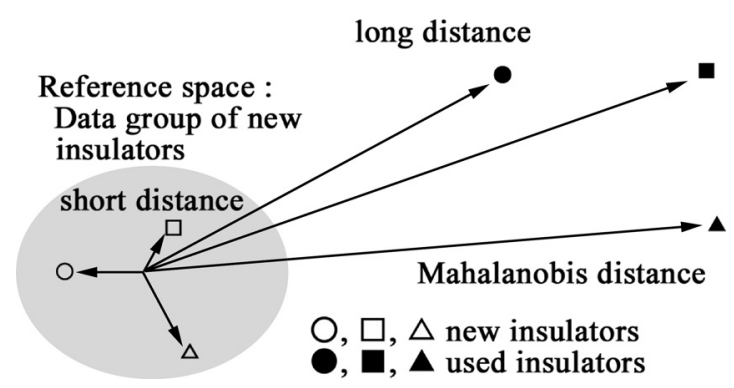

図 1 MT 法による絶縁劣化評価の概念

Fig. 1. Concept chart of evaluation of insulators using the MT Method.

〈3·3〉 加速劣化試験 絶縁物劣化メカニズムを検証 するために加速試験を行った。硝酸が入ったビーカーと絶 縁物 $(5 \times 5 \mathrm{~cm})$ をデシケーター $(30 \times 30 \times 22 \mathrm{~cm})$ に入 れ, 硝酸曝露試験を実施した。試験条件は, 硝酸濃度 $8 \mathrm{~N}$, 温度 $25^{\circ} \mathrm{C}$, 試験時間 5 9 日間である。試験後の絶縁物を $50^{\circ} \mathrm{C}, 1$ 時間で乾燥し, 分析を実施した。

〈3・4〉 MT 法 MT 法は様々な情報を総合して1つ の物差しで判断する技術で, 品質工学の 1 手法である。正 常なサンプルのデータから評価の基準となるデータ群（基 準空間）を作成して，基準空間からの乘離度で評価対象の 劣化度を判断する（図 1)。乘離度は従来から統計学の分野 で使用されているマハラノビスの距離 (5)を用いて表し, 距 離が大きいほど劣化度が大きいと判断する。MT 法は製品 の外観検査, 文字認識, 官能検査, 健康診断, 故障診断等 の分野で適用されている。本論文では, データ処理方法は 割愛する（文献 $(5) \sim(7)$ 参照)。

\section{4. 結果と考察}

\section{$\langle\mathbf{4} \cdot 1\rangle \quad$ 絶縁物の評価結果}

$\langle\mathbf{4} \cdot \mathbf{1} \cdot \mathbf{1}\rangle$ 外観観察結果遮断器用モールドフレーム (絶縁物) の外観観察結果を図 2 に示す。絶縁物の遮断器設 置側と設置裏側を目視で観察した結果, 遮断器設置裏側の 全面に塵埃が付着していた。遮断器設置裏側と比較して遮 断器設置側の方が表面抵抗率の低下が大きかったため, 絶 縁物の評価は遮断器設置側の導体支持部付近について実施 した。

$\langle\mathbf{4} \cdot \mathbf{1} \cdot \mathbf{2}\rangle$ 色彩・光沢測定結果色彩測定結果を図 3 に, 光沢測定結果を図 4 に示す。色彩は Lab 表示モードで 表した。色彩 L は明度，色彩 a のプラス方向は赤，マイナ ス方向は緑，色彩 $\mathrm{b}$ のプラス方向は黄色，マイナス方向は 青を示す。色彩, 光沢の測定值は基準值との相対值で示し た。新品と比較して市場使用品の色彩 L は低下しているサ ンプルがあった。色彩 $\mathrm{a}$ は変化がなかったが, 色彩 $\mathrm{b}$ は増 加する傾向があった。市場使用品の光沢は低下する傾向が あった。

$\langle\mathbf{4} \cdot \mathbf{1} \cdot \mathbf{3}\rangle$ 赤外分析による成分分析結果 赤外分析に よる成分分析結果を図 5 に示す。赤外スペクトルから各成 分のピーク面積を求め, 絶縁物の充填材である炭酸カルシ

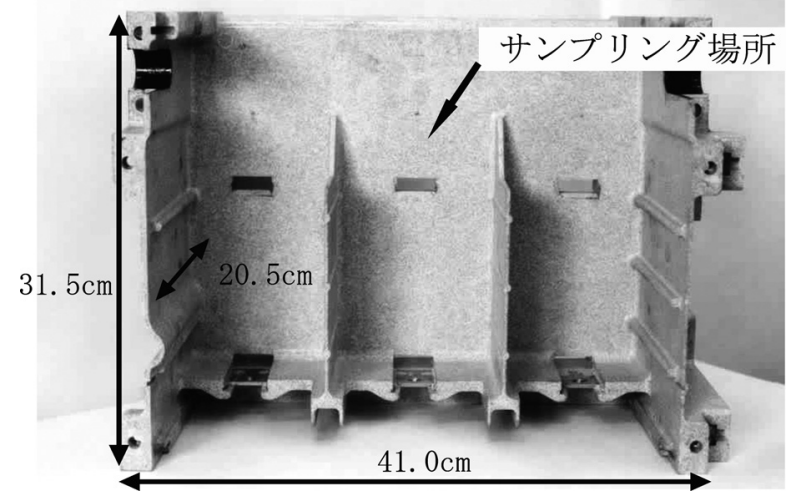

(a) 遮断器設置側

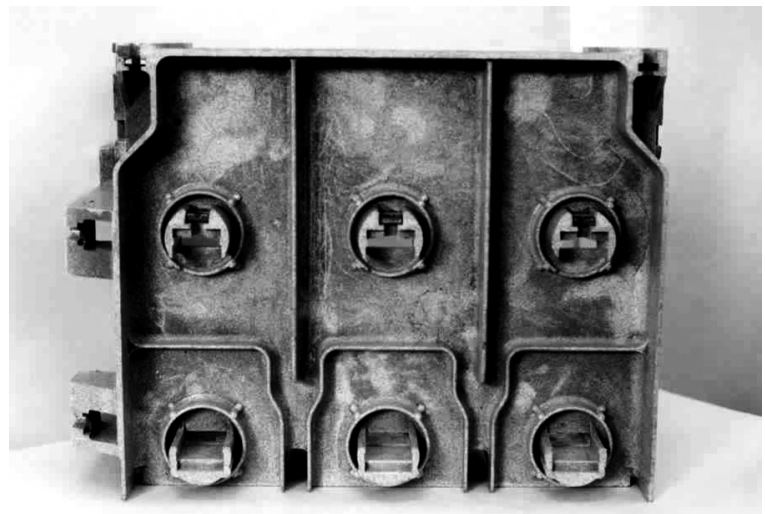

(b) 遮断器設置裏側

図 2 外観観察結果

Fig. 2. Observation results of a insulator.

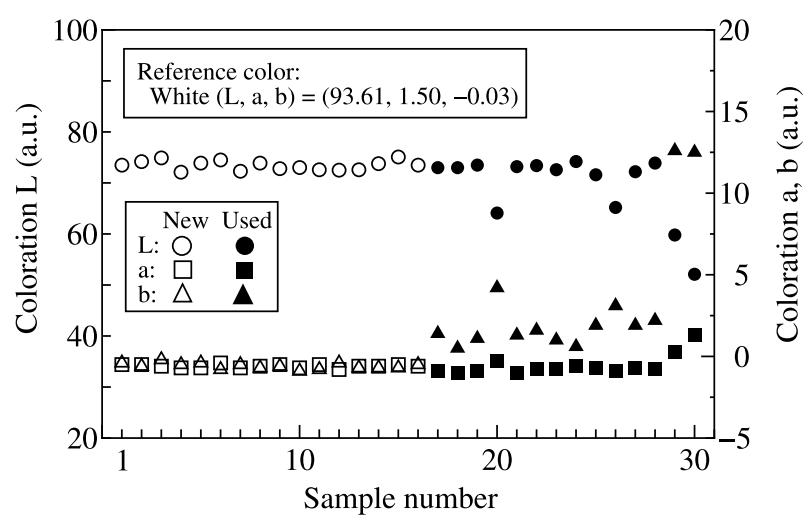

図 3 色彩 $(L, a, b)$ 測定結果

Fig. 3. Coloration (L, a, b) measurement results.

ウムのピーク面積に対する比で各成分を表した。新品と比 較して市場使用品の水, 硫酸塩, 硝酸塩, ケイ酸塩は増加 する傾向があった。炭化水素, エステルはほとんど変わら なかった。硫酸塩, 硝酸塩はカルシウム塩として存在し潮 解性であるため, 市場使用品では水の付着が見られ, 表面 抵抗率が低下すると考えられる。

〈4·1·4〉 イオン付着量分析結果 イオン付着量分析 結果を図 6, 図 7 に示す。新品と比較して市場使用品の硝 酸, 硫酸, 塩素の各院イオン濃度とナトリウムイオン濃度 


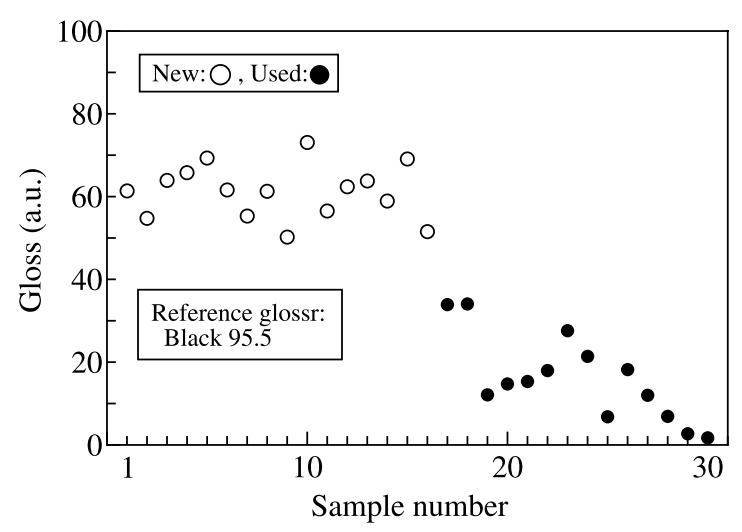

図 4 光沢測定結果

Fig. 4. Gloss measurement results.

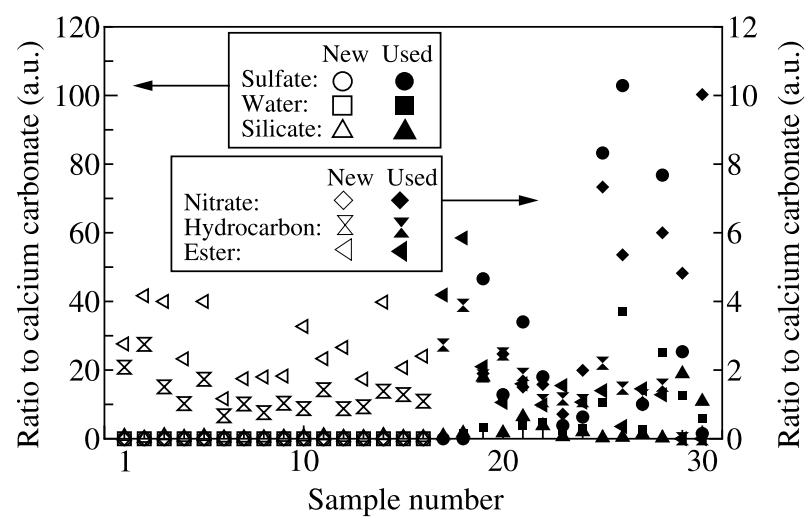

図 5 赤外分析結果

Fig. 5. Infrared analysis results.

は増加する傾向があった。陰イオンの主成分は硝酸イオン と硫酸イオンであった。赤外分析と相関する結果であり， 硝酸カルシウム, 硫酸カルシウムがイオン化していると考 えられる。陽イオンの主成分はカルシウムイオンであり他 の陽イオンの 50１00 倍であった。これは絶縁物に充填材 として含まれている炭酸カルシウムが原因だと考えられる。 遮断器の設置場所, 区分と絶縁物付着硝酸, 硫酸イオン濃 度との関係を表 4 に示す。硝酸イオン, 硫酸イオン濃度と も東京，神奈川等の大都市の屋外キュービクルで高い傾向 があった。中小都市と比較して大都市では大気中の NOx, SOx が多いことから, 絶縁物表面の硝酸, 硫酸イオン濃度 にはNOx，SOx が影響していると考えられる。

$\langle\mathbf{4} \cdot \mathbf{1} \cdot \mathbf{5}\rangle$ 表面抵抗率測定結果 表面抵抗率の測定結 果を図 8 に示す。表 3 に示した通り, ギャップが $0.3 \mathrm{~mm}$ の櫛形電極を絶縁物に蒸着し, 温度 $20^{\circ} \mathrm{C}$, 湿度 $\mathrm{RH} 50 \%$ の 条件下で表面抵抗率を測定した。赤外分析とイオン測定の 結果から, 新品と比較して市場使用品の表面抵抗率が約 4 8 桁低下しているのは前記の通り，イオン性物質が原因た と考えられる。

$\langle\mathbf{4 \cdot 1 \cdot 6 \rangle}$ 化学的分析結果のばらつき 化学的分析の 各項目ごとに求めた変動係数を, 表面抵抗率実測值の変動 係数とともに表 5 に示す。化学的分析，表面抵抗率とも新

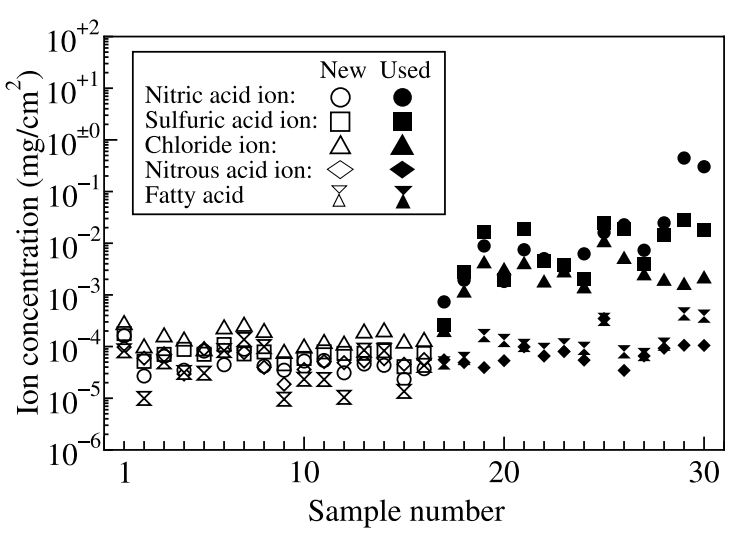

図 6 院イオン分析結果

Fig. 6. Anion measurement results.

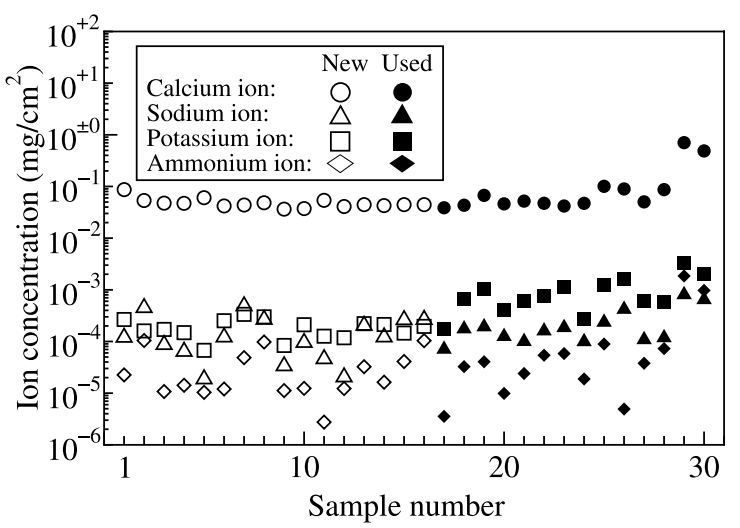

図 7 陽イオン分析結果

Fig. 7. Cation measurement results.

表 4 遮断器の設置場所, 区分とイオン付着量 との関係

Table 4. Relationship between Location, cubicle type of breakers and ion concentration.

\begin{tabular}{llll}
\hline $\begin{array}{l}\text { Nitric } \\
\text { acid ion } \\
\left(\mathrm{mg} / \mathrm{cm}^{2}\right)\end{array}$ & $\begin{array}{c}\text { Sulfuric } \\
\text { acid ion } \\
\left(\mathrm{mg} / \mathrm{cm}^{2}\right)\end{array}$ & \multicolumn{1}{c}{ Location } & Cubicle type \\
\hline $7.32 \times 10^{-4}$ & $2.62 \times 10^{-4}$ & Hino City, Tokyo & Indoor type \\
$1.82 \times 10^{-3}$ & $1.93 \times 10^{-3}$ & Matsuto City, Ishikawa & Indoor type \\
$1.93 \times 10^{-3}$ & $2.78 \times 10^{-3}$ & Hikawa-gun, Shimane & outdoor type \\
$3.24 \times 10^{-3}$ & $3.80 \times 10^{-3}$ & Tohaku-gun, Tottori & outdoor type \\
$5.03 \times 10^{-3}$ & $4.48 \times 10^{-3}$ & Akeshi City, Hyogo & outdoor type \\
$6.23 \times 10^{-3}$ & $2.05 \times 10^{-3}$ & Saku City, Nagano & outdoor type \\
$7.32 \times 10^{-3}$ & $3.95 \times 10^{-3}$ & Osaka City, Osaka & outdoor type \\
$7.48 \times 10^{-3}$ & $1.91 \times 10^{-2}$ & Adachi-ku, Tokyo & outdoor type \\
$8.85 \times 10^{-3}$ & $1.65 \times 10^{-2}$ & Chuo-ku, Tokyo & outdoor type \\
$1.61 \times 10^{-2}$ & $2.46 \times 10^{-2}$ & Nagoya City, Aichi & outdoor type \\
$2.28 \times 10^{-2}$ & $1.85 \times 10^{-2}$ & Nerima-ku, Tokyo & outdoor type \\
$2.48 \times 10^{-2}$ & $1.42 \times 10^{-2}$ & Omiya City, Saitama & outdoor type \\
$3.02 \times 10^{-1}$ & $1.78 \times 10^{-2}$ & Ota-ku, Tokyo & outdoor type \\
$4.46 \times 10^{-1}$ & $2.76 \times 10^{-2}$ & Konan-ku, Kanagawa & outdoor type \\
\hline
\end{tabular}

品絶縁物のデータを対象とした。化学的分析の変動係数は $0.11 \sim 0.70$, 表面抵抗率の変動係数は 0.39 であることから, 化学的分析は表面抵抗率と同レベルのばらつきで分析可能 であることを確認できた。 


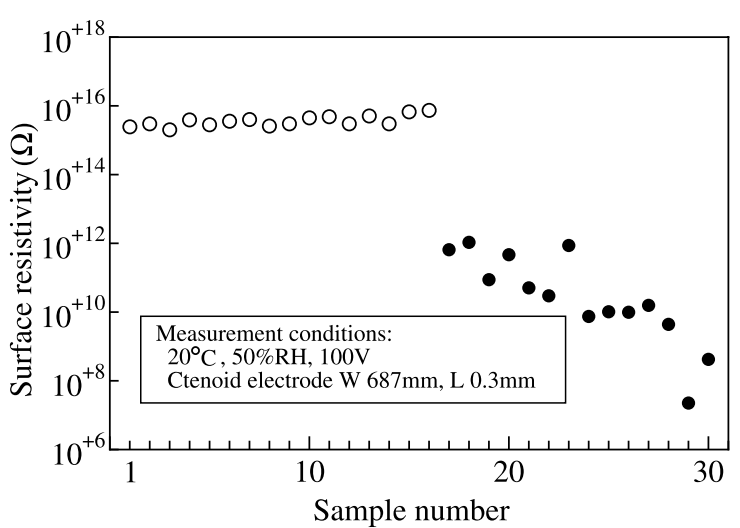

図 8 表面抵抗率測定結果

Fig. 8. Measurement results of surface resistivity.

表 5 化学的分析結果のばらつき

Table 5. Variation of chemical analysis results.

\begin{tabular}{lc}
\hline \multicolumn{1}{c}{ Analysis item } & Coefficient of variation(a.u.) \\
\hline Coloration & 0.21 \\
Gloss & 0.11 \\
Infrared analysis & 0.43 \\
Anion & 0.53 \\
Cation & 0.70 \\
Surface resistivity & 0.39 \\
\hline
\end{tabular}

$\langle 4 \cdot 2\rangle$ 表面抵抗率低下メカニズムの解明

$\langle\mathbf{4} \cdot \mathbf{2} \cdot \mathbf{1}\rangle$ 表面抵抗率低下メカニズムの想定＼cjkstart評価結 果から絶縁物の市場使用品について以下のことが分かった。

（1）赤外分析とイオン測定の結果から, 絶縁物付着イ オンの主成分は硝酸イオン, 硫酸イオン, カルシウ ムイオンであり，これらは潮解性の化合物である硝 酸カルシウム, 硫酸カルシウムとして存在していた。

（2）絶縁物の化学的分析は塵埃の付着が見られない遮 断器設置側について実施したことから, 硝酸カルシ ウム, 硫酸カルシウムの付着は塵埃と関係しない。

（3）地方より都市部に設置していた遮断器用絶縁物の 方が硝酸イオン濃度, 硫酸イオン濃度が高く, 大気 中の NOx，SOx が影響していると考えられる。

これらの結果から，NOx，SOx が表面抵抗率の低下に関 係していると考えられる。NOxによる絶縁物の表面抵抗 率低下メカニズムは図 9 のように想定できる。大気中の $\mathrm{NOx}\left(\mathrm{NO}_{2}\right)$ が硝酸 $\left(\mathrm{HNO}_{3}\right)$ になり, 絶縁物の充填材で ある炭酸カルシウム $\left(\mathrm{CaCO}_{3}\right)$ と反応して硝酸カルシウム $\left(\mathrm{Ca}\left(\mathrm{NO}_{3}\right)_{2}\right)$ が生成する。硝酸カルシウムは潮解性のイオ ン性化合物であるので，吸湿した水に溶け込みイオン化し て, 絶縁物の表面抵抗率を低下させると考えられる。以上 より表面抵抗率が低下するのは, 大気中の NOx, SOx が原 因で硝酸カルシウム, 硫酸カルシウムが生成することが主 要因だと考えられる。

$\langle\mathbf{4 \cdot 2 \cdot 2 \rangle}$ 想定したメカニズムの検証 大気中の NOx による絶縁物の表面抵抗率低下メカニズムを検証するため に，デシケーター中で絶縁物を硝酸に曝露する加速試験を

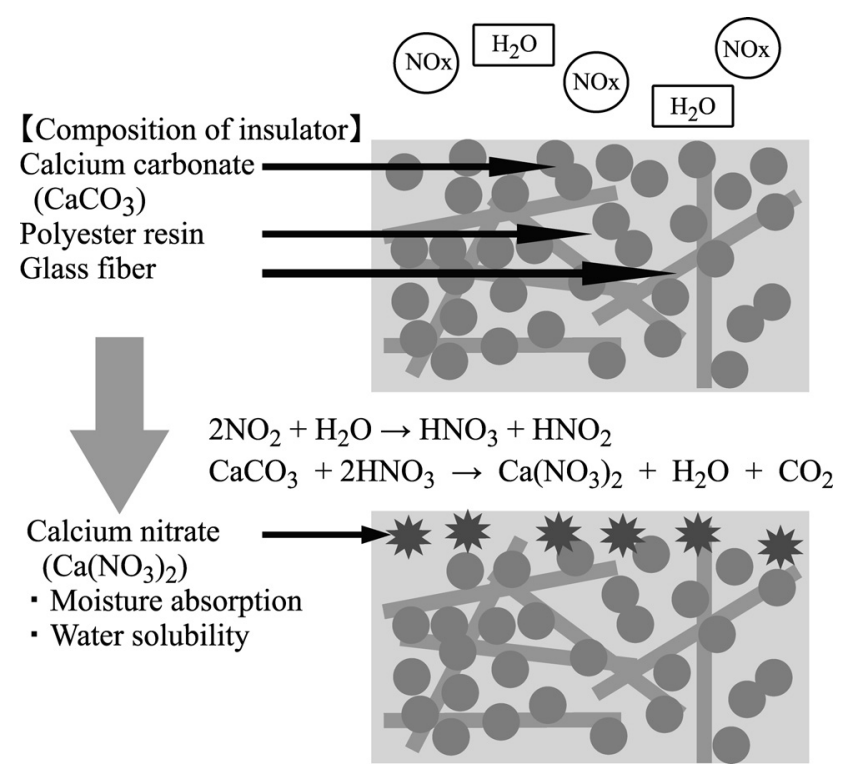

図 9 表面抵抗率低下メカニズム

Fig. 9. Mechanism of surface resistivity reduction.

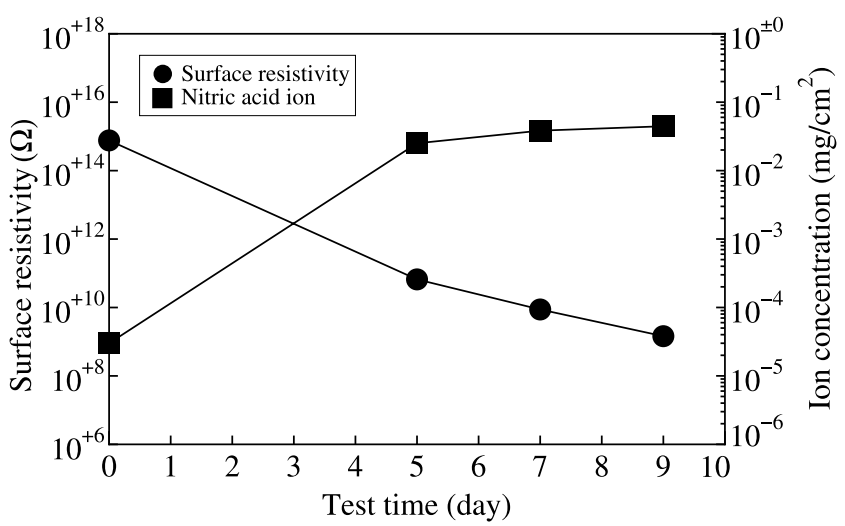

図 10 絶縁物加速試験品の表面抵抗率と イオン付着量測定結果

Fig. 10. Measurement results of surface resistivity and ion concentration of acceleration test samples.

行った。試験後の絶縁物の表面抵抗率と硝酸イオン濃度の 測定結果を図 10 に示す。試験時間とともに表面抵抗率は 低下し, 硝酸イオン濃度は増加した。硝酸イオン濃度の増 加の傾向と表面抵抗率の低下の傾向が一致していることか ら，硝酸イオンが表面抵抗率の低下に影響していることを 確認することができた。試験後の絶縁物の赤外分析結果を 新品, 市場使用品の結果とともに図 11 に示す。試験後の 絶縁物には新品に見られない硝酸カルシウムが存在してい たことから, 硝酸イオンは硝酸カルシウムとして存在する ことが明確になった。また, 市場使用品も硝酸カルシウム が生成しているいことを確認できた。SOxの場合も同じ無 機酸である硫酸が発生することから, 同様の反応が起こる。 以上から大気中の NOx, SOx により生成した硝酸カルシウ ム, 硫酸カルシウムが主要因となり, 絶縁物の表面抵抗率 が低下するメカニズムは妥当であると考えられる。 


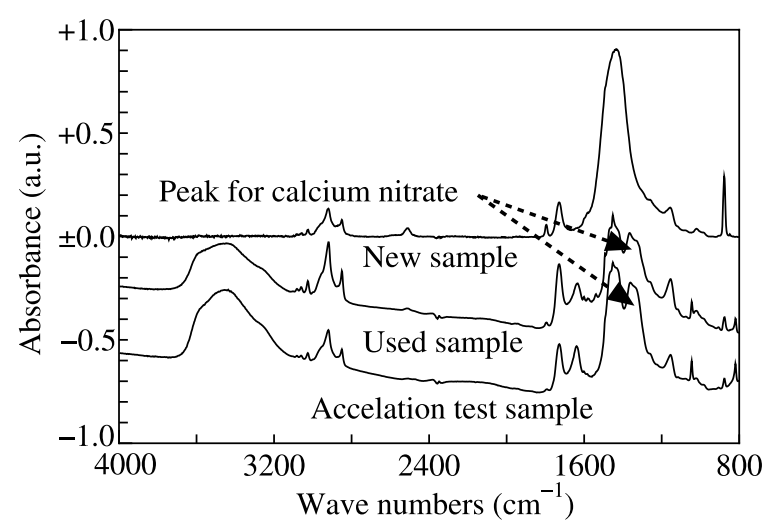

図 11 絶縁物加速試験品の赤外分析結果

Fig. 11. Infrared analysis results of acceleration test samples.

表 6 MT 法に適用した評価項目

Table 6. Evaluation item for the MT Method.

\begin{tabular}{llllll}
\hline No. & Evaluation item & No. & Evaluation item & No. & Evaluation item \\
\hline A & Coloration (L) & F & Silicate & K & Sulfuric acid ion \\
B & Coloration (b) & G & Fatty acid & L & Sodium ion \\
C & Gloss & H & Chloride ion & M & Ammonium ion \\
D & Hydrocarbon & I & Nitrous acid ion & N & Potassium ion \\
E & Ester & J & Nitric acid ion & O & Calcium ion \\
\hline
\end{tabular}

〈4·3〉 MT 法による絶縁劣化評価

$\langle\mathbf{4 \cdot 3 \cdot 1 \rangle}$ 評価に用いた項目評価に用いた項目は以 下とした。劣化メカニズムから硝酸イオン, 硫酸イオン, 及びカルシウムイオンは評価項目として必須である。色彩 a (色彩測定), 硝酸塩, 硫酸塩, 水 (以上 3 項目は赤外分 析）の 4 項目は評価対象から除外し，上記 3 項目を含む 15 個の評価項目（表 6）を用いた。色彩 $\mathrm{a}$ は新品，市場使用 品とも測定結果にほとんど変化がないこと，硝酸塩，硫酸 塩は水に溶けてイオン化すると硝酸イオン，硫酸イオンに なるため, 評価項目として取り挙げている硝酸イオン, 硫 酸イオンと等価であること, 及び水は硝酸カルシウム等の 吸湿により検出された測定值であり，湿度により測定值が 異なることが理由である。

〈4·3・2〉 MT 法による絶縁劣化評価結果 上記 15 項 目の評価結果から求めたマハラノビスの距離と表面抵抗率 の実測值 (図 8 参照) との関係を図 12 に示す。マハラノビ スの距離と表面抵抗率は良好な相関（相関係数 0.96）を示 すことから，化学的分析結果にMT 法を適用することによ り絶縁劣化評価が可能であることを検証できた。絶縁抵抗 測定や部分放電測定では検出可能な範囲は約 $10^{9} \Omega$ 以下で あり，今回の市場使用品のほとんどが異常なしとの判定し かできない。これらの方法は劣化度が分からないため評価 法として不十分であるのに対して，本手法では全てのサン プルについて劣化度を評価可能である。本手法では $10^{9}$ ～ $10^{16} \Omega$ の範囲の絶縁物に対しても評価可能であるので，電 気的評価法と比較して評価可能な範囲を 7 桁程度拡大する ことができた。

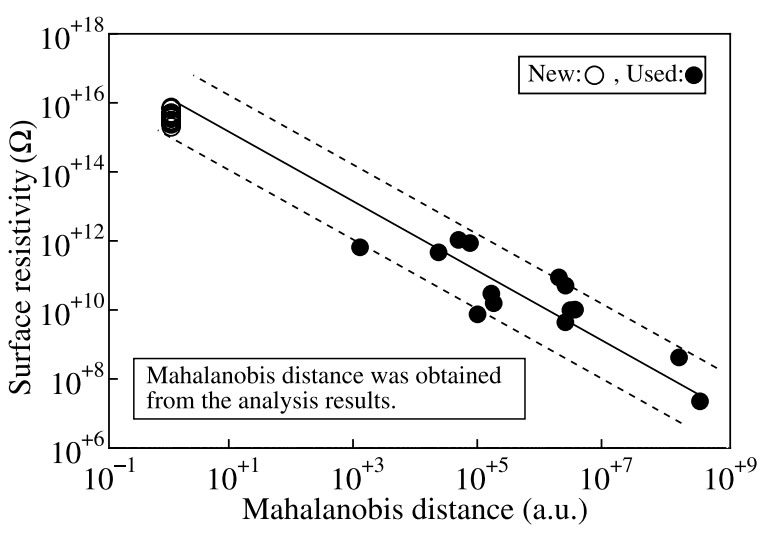

図 12 マハラノビスの距離と表面抵抗率の関係

Fig. 12. Relationship between the Mahalanobis distance and surface resistivity.

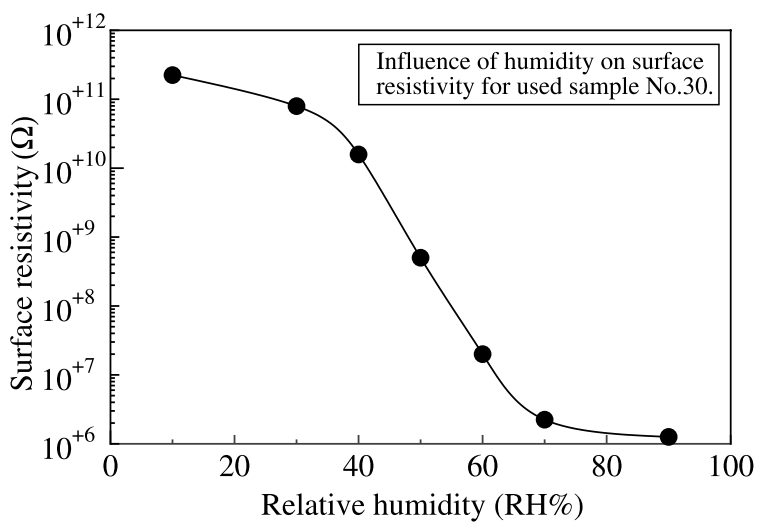

図 13 表面抵抗率の湿度依存性

Fig. 13. Influence of humidity on surface resistivity.

市場使用品 No.30 について，表面抵抗率の湿度依存性 を図 13 に示す。市場使用品 No.30 の表面抵抗率は湿度

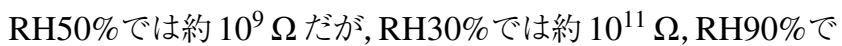
は約 $10^{6} \Omega$ となり，湿度条件を一定に決めて測定しなけれ ば表面抵抗率は大きく変化する。測定する季節や時間によ り湿度が変化するため, 電気的評価法では抵抗測定值や放 電開始抵抗值は 5 桁程度バラツク可能性がある。図 12 に 示す通り，開発した手法は平均值 \pm 1 桁 $(\Omega)$ 程度のバラツ キなので, 電気的評価法と比較して精度が 3 桁程度改善す ると考えられる。

以上から本手法の適用により絶縁物の劣化度を電気的な 異常が発生する前に, 定量的に精度良く評価可能であるこ とが分かった。

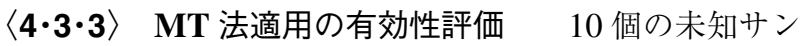
プルを用いて MT 法の有効性を評価した。未知サンプルは 今回使用した 14 個の市場使用品と異なるサンプルである。 今回使用した新品, 市場使用品の合計 30 サンプルから硝 酸イオン濃度と表面抵抗率の相関直線を求め, 図 14(a)に 示した。この図に未知サンプルの硝酸イオン濃度と表面抵 抗率測定值をプロットした結果から, 硝酸イオン濃度のみ で評価すれば 2 桁程度の誤差が生じることが分かる。同様 


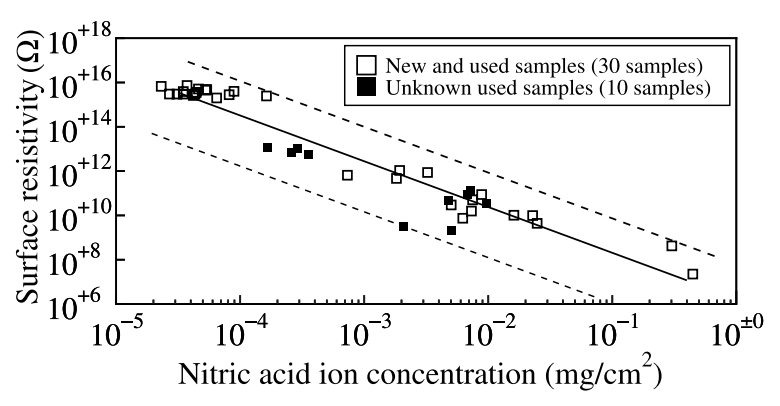

(a) Deterioration diagnosis using nitric acid ion concentration

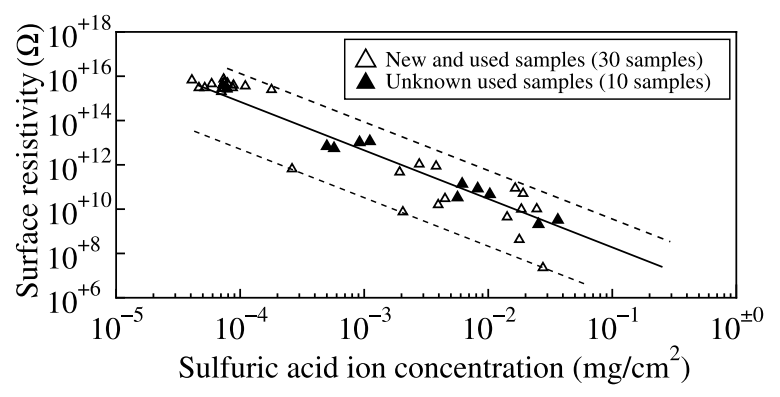

(b) Deterioration diagnosis using sulfuric acid ion concentration

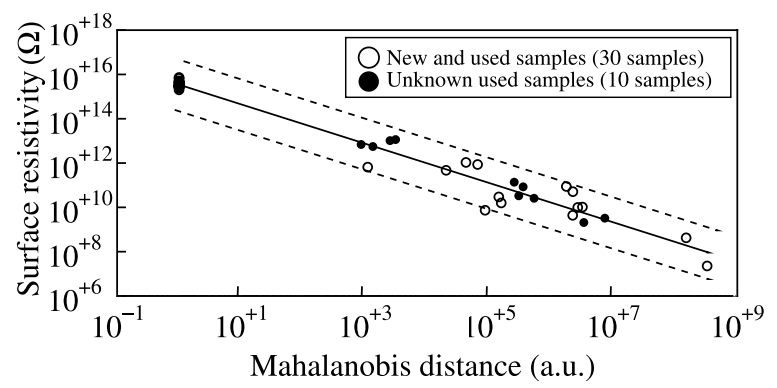

(c) Deterioration diagnosis using MT method

図 14 MT 法適用の有効性評価結果

Fig. 14. Effectiveness evaluation results of the MT method application.

に硫酸イオン濃度と表面抵抗率測定值の関係（図 14(b)）か ら表面抵抗率を推定すると 2 林程度の誤差が生じる。

マハラノビスの距離と表面抵抗率測定值の関係を同様に プロットした結果を図 14(c) に示す。今回使用したサンプ ル，未知サンプルとも，相関直線を用いて求めた表面抵抗 率の推定值は誤差が 1 桁以内であった。これより硝酸イオ ン濃度, 硫酸イオン濃度のみで表面抵抗率を求める場合と 比較して MT 法を用いると, 約 1 桁評価精度が改善し, 表 面抵抗率の推定值は 95\%の信頼度で平均值 \pm 1 椼 $(\Omega)$ の 間にあることが分かった。

$\langle\mathbf{4} \cdot \mathbf{3} \cdot \mathbf{4}\rangle$ 他の絶縁物への展開他の絶縁物への本技 術の展開可否を評価するために, 木粉基材フェノール絶縁 物（図 15）についても同様に評価を実施した。ポリエステ ル絶縁物と同様にフェノール絶縁物の新品, 使用品の合計 24 サンプルを化学的方法により分析し, 分析結果を MT 法 で評価した。マハラノビスの距離と表面抵抗率の実測值と の関係を図 16 に示す。マハラノビスの距離と表面抵抗率

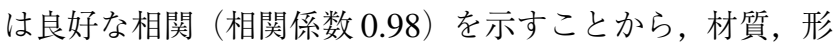

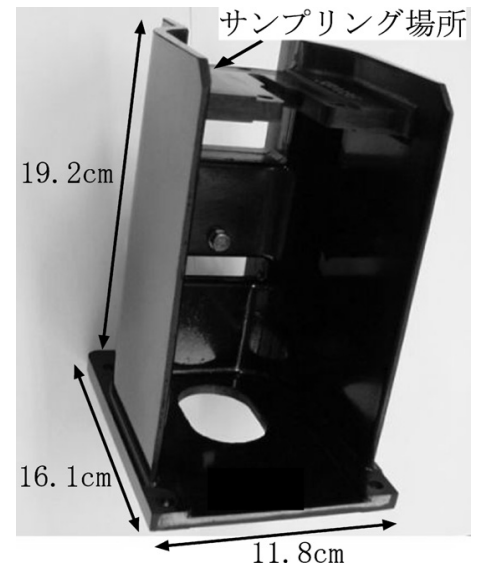

図 15 フェノール絶縁物

Fig. 15. Phenol insulator.

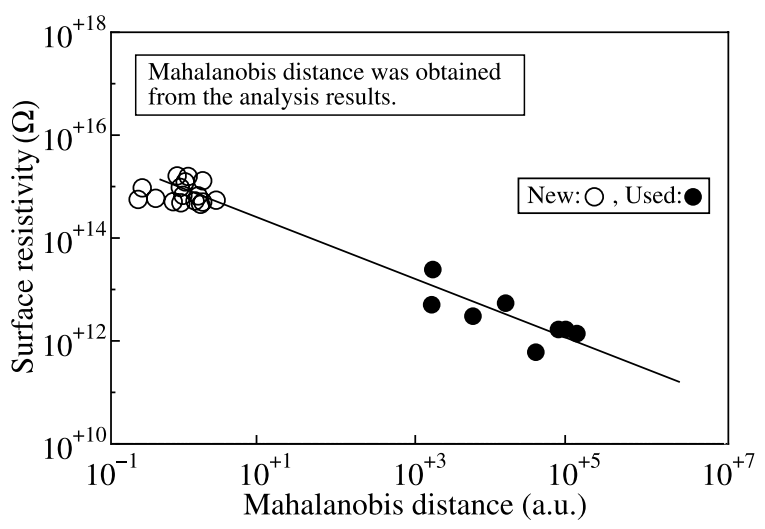

図 16 フェノール絶縁物に対するマハラノビス の距離と表面抵抗率の関係

Fig. 16. Relationship between the Mahalanobis distance and surface resistivity for phenol insulators.

状等が異なる絶縁物に対しても本技術が有効であることを 確認できた ${ }^{(8)}$ 。

\section{5. まとめ}

本論文では絶縁劣化評価精度の向上と評価可能な範囲の 拡大を目的に, 化学的方法で遮断器用絶縁物を分析し, 分析 結果をMT法で評価した。得られた結果を以下にまとめる。

（1）絶縁物の化学的分析結果をMT 法で評価した結果 と表面抵抗率の実測值は良好な相関を示したことから, 本 手法を適用することにより絶縁劣化評価が可能であること を明確にした。

（2）絶縁抵抗測定等の電気的評価法と比較して, 本手 法では評価精度は約 3 桁改善し, 評価可能な範囲は約 7 桁 拡大することができた。本手法の適用により電気的な異常 が発生する前に, 定量的に精度良く評価することが可能と なる。

（3）絶縁物市場使用品の分析と加速試験から, 今回評 価した遮断器絶縁物の表面抵抗率低下メカニズムは以下で あることを明確にした。大気中の NOx, SOx が原因で硝酸 
カルシウム，硫酸カルシウムが生成する。これらは潮解性 のイオン性化合物であるので，吸湿した水に溶け込みイオ ン化して絶縁物の表面抵抗率を低下させる。

（4）材質, 形状等が異なる絶縁物に対しても本技術が 有効であることを確認できた。

(平成 18 年 12 月 28 日受付，平成 19 年 3 月 30 日再受付)

\section{文献}

（1）河村達雄・田中祀捷：電気設備の診断技術, 電気学会編, オーム社 (2003)

（2）設備診断更新技術調査専門委員会編：「工場電気設備の診断・更新 技術」, 電気学会技術報告, No.831 (2001)

（3） 絶縁材料の劣化と機器・ケーブルの絶縁劣化判定調查専門委員会編： 「絶縁材料の劣化と機器・ケーブルの絶縁劣化判定の実態」, 電気学 会技術報告, No.752 (2000)

(4) T. Watanabe, I. Kasama, H. Ishii, and Y. Takagi: "Partial Discharge Detector for Substation Predictive Maintenance System", T. IEE Japan, Vol.116-B, No.1, pp.65-73 (1996-1) (in Japanese) 渡部剛士・笠間一郎・石井秀和・高木義之 : 「受配電設備診断用部分 放電検出装置」, 電学論 B, 116, 1, pp.65-73 (1996-1)

(5) M. Qunigoh: "An Introduction to Mahalanobis Distance for MTS Methods", Quality Engineering, Vol.9, No.1, pp.13-21 (2001-1) (in Japanese) 救仁郷誠:「マハラノビスの距離 入門」, 品質工学, 9, 1, pp.13-21 (2001-1)

（6）田口玄一・兼高達戴：「MT システムに打ける技術開発」, 品質工学応 用講座, 日本規格協会 (2002)

(7) S. Miki and H. Okazawa: "Diagnosis of the Degradation of Insulating Material Using the Mahalanobis-Taguchi System Method", The Paper of Technical Meeting on General Industry, IEE Japan, GID-01-24, pp.21-26 (2001) (in Japanese)

三木伸介・岡澤 周:「絶縁劣化診断へのマハラノビス・タグチシス テム法の適用」, 電気学会一般産業研資, GID-01-24, pp.21-26 (2001)

(8) S. Miki and H. Okazawa: "Degradation Diagnosis of the Insulators for the Power Distribution Equipments Using the Mahalanobis-Taguchi Method", The Paper of Joint Technical Meeting on Electrical Discharge, Switching and Protecting Engineering, IEE Japan, ED-05-121, SP-05-59, HV-05-63, pp.49-54 (2005) (in Japanese)
三木伸介·岡澤 周:「MT 法による受配電機器絶縁物の劣化診断」, 電気 学会放電・開閉保護・高電圧合同研資, ED-05-121, SP-05-59, HV-05-63, pp.49-54 (2005)
三木伸 介

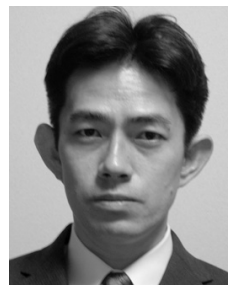

岡 澤

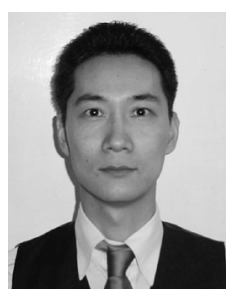

犬 島

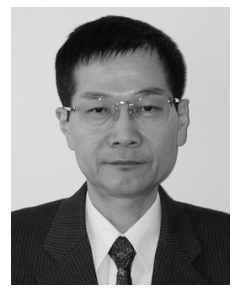

（正員） 1993 年大阪府立大学大学院工学研究科 修士課程修了。同年三菱電機（株）入社。先端技 術総合研究所において, 主として有機材料や潤滑 油の評価・診断に関する研究に従事。
周 (非会員) 1998 年姫路工業大学工学部機械工学 科を卒業。同年三菱電機（株）入社。現在，三菱 電機（株）受配電システム製作所受配計課に勤務 し，主に予防保全技術開発，予防保全活動に従事。
(正員) 1975 年北海道大学工学部電子工学科卒。 同年, 三菱電機 (株) 入社。同社中央研究所, 産業 システム研究所に所属。プラント・機器の診断・ 監視・制御に関する研究に従事。2002 年 4 月か ら, 早稲田大学大学院情報生産システム研究科・ 教授。工学博士。1991 年電気学会論文賞受賞。電 気学会, 日本原子力学会, 計測自動制御学会, 情 報処理学会会員。 